\title{
Technical and Economic efficiency of the ruminants feed on Date Seed in Matrouh
}

\section{Governorate}

\author{
Sherine .F. Mansour ${ }^{1}$, Moharram .F. El-Bassiony², Ahmed. S. El-Hawy ${ }^{3}$
}

${ }^{1}$ Socio-Economic Division, Desert Research Center, El Mataria, Cairo, Egypt. sherine.2050@hotmail.com

${ }^{2,3}$ Division of Animal and Poultry Production, Animal and Poultry Physiology Department, Desert Research Center,El Mataria, Cairo, Egypt.

*Division of Animal and Poultry Production, Animal and Poultry Physiology Department, Desert Research Center, El Mataria, Cairo, Egypt.

Abstract - Ruminants occupies an advanced rank between farm livestock,, due to its suitability to life under difficult environmental conditions, especially in Egyptian desert governorates.

The high cost of sheep and goat nutrition lead to low the animal meat unit productivity, and low the producer's profit, which facing many investors in the field of sheep and goat breeding in the Egyptian desert governorates.The problem of the study is the high cost of ruminants nutrition (around $60 \%$ from the variable total costs), despite there are many high nutrition values of agriculture residues which can enter in the composition of nutrition diet for sheep and goat.

The research aims identify the optimal diet for fatting ruminants in order to maximize the productivity of sheep on one side and on other hand to minimize the cost of sheep nutrition.The research was based on the results of the experiment, that was carried out during the period from April 2017 to March 2018 at Matrouh Resource Development Center, that belongs to the Desert Research Center. The main result is that date seeds as a cheap source of energy, might be used successfully and economically in small ruminant rations during different physiological stages without adverse effects, due to estrogen-like compounds, on their productive and reproductive performance.

Keywords-Ruminants feed, date seed, Matrouh, Technical efficiency, Economic efficiency.

\section{INTRODUCTION}

Small ruminants (goats and sheep) are a major component of the economic activity and social system of the people of the desert areas of the Arab Republic of Egypt. These animal species are distributed as animals adapted to the natural ecosystem and are the main source of human food (milk and meat). These animals have the appropriate development of their potential as other farm animals, due to their association with dry natural pasture areas in Egypt.

Small ruminants suffer from nutritional, reproductive and health problems in these areas, resulting in low productivity, poor disease resistance and high mortality in their young ones, which hinders the development of their production of milk, meat, leather, wool, wool, hair and other products of great importance to the people of the desert areas.
Owing to the shortage and high costs of animal feeds, especially the grains where a large proportion of it is imported to the country, it becomes necessary to use the industrial or agricultural by-products as a compensatory feeds in animal feeding. The gap between the availability and requirements of feeds is wide and the estimated shortage tended to increase from 3.1 (Abou-Akkada, 1988) to 4.92 million tons TDN by the year 2000 (El-Shazely, 1988). Several efforts were carried out to use local byproducts (such as date seeds) in animal feeding as an attempt to solve feed shortage problems.

Dates Phoenix dactylifera L. are very popular in most of the Middle Eastern countries. Over $70 \%$ of the total world production is produced in this area. Egypt is the second important country in date world production which produces $1,166,182$ tons (FAO, 2004), where the seeds represent 
about $20.8 \%$ (Kholif, 1997). One hundred and twenty thousand tons of seeds may be used as a feedstuff which is very rich in carbohydrates and amino acids (El-Boushy, 1990). Date seeds had a higher TDN value and contained relatively high percent of fat with a high coefficient of digestibility (Abou El-Naser, 1985). Many workers had reported that date seeds could be used economically and successfully for ruminants' nutrition; they could be used as an energy source to replace a part of concentrates in the ration (Al-Dabeeb, 2005). Date seeds supplemented diets might improve animal performance due to growth stimulating hormones (as estrone, $1.9 \mathrm{mg} / \mathrm{kg}$ ) that were found in date seeds (Barreveld, 1993).

\section{Research Objectives}

- Determine the estrogen-like compounds concentrations in the date seeds and their effects on estrus cyclicity, hormonal profiles and reproductive performance as well as productive efficiency of Barki ewes when fed on date seeds.

- Determine the optimum diet in order to maximize the productivity of small ruminants

- $\quad$ Reduce the cost of nutrition, allowing small-scale farmers to continue to produce optimal production, particularly in desert areas of relative importance in the production of these ruminants.

\section{METHODOLOGY}

The physiological experiment was conducted to determine estrogen-like compounds concentrations in the date seeds and their relation to estrus cyclicity, hormonal profiles and reproductive performance as well as productive efficiency ofsmall ruminants ( Barki ewes) fed the date seeds as a partial or full replacer of yellow corn in the concentrate ration by either $50 \%$ or $100 \%$ over full reproductive cycle.

The research was based on descriptive analysis; Also use the nutrition problem model (using linear programming method) as one of the methods of process research for the formation of homozygous in the field of small ruminants.

\section{Sampling and Data collection}

The research was based on the results of the experiment, that was carried out during the period from April 2017 to March 2018 at Matrouh Resource Development Center, that belongs to the Desert Research Center. Seventy five Barki ewes (2.0-2.5 years old and $37.8 \pm 0.63 \mathrm{~kg}$ average body weight) were assigned into three groups (25 each). First group (G1) was served as control ( $0.0 \%$ date seeds) and fed a concentrate ration consisted of $43 \%$ yellow corn, $22 \%$ cotton seed meal, 20\% wheat bran, $12 \%$ rice bran, $1.5 \%$ limestone, $1 \%$ sodium chloride and $0.5 \%$ minerals mixture. Date seeds were used as a partial or full replacement of the yellow corn in the concentrate ration by either $50 \%(\mathrm{G} 2)$ or $100 \%$ (G3). All ewes groups were offered barseem (Trifoliumalexandrnum) hay ad libitum, as a basal roughage diet, and rations were adjusted monthly to cover their requirements during their physiological status according to Kearl (1982). Water was available to all groups twice daily.

Animals were kept in semi-open pens roofed with wood, and were clinically healthy and free from internal and external parasites.Mating season started in June and lasted for 51 days (equal to 3 estrous cycles). Five fertile rams were allowed to rotate among different ewes groups to avoid sire/group confounding effect. Rams were fed the control concentrate ration and removed from the ewes groups at early morning before offering rations.

Once lambing took place, the born lambs were earing tagged and weighed to record their birth weight. Lambs were left with their dams till 3 months (90 days), then weaned and weaning weight was recorded and adjusted for 90 days.

\section{Statistical analysis}

First theTechnical Experience: Data of estrus activity was analyzed using "all or non traits" according to Snedecor

and Chocran (1980), while continuous data were subjected to an analysis of variance utilizing GLM model of SAS for repeated measurements and means were compared using Duncan Multiple Range Test. Model 1 (for birth, weaning and marketing weights)

$\mathbf{Y}_{\mathbf{i j}}=\boldsymbol{\mu}+\mathbf{T}_{\mathbf{i}}+\mathbf{e}_{\mathbf{i j}}$

Where:

$$
\begin{aligned}
& Y_{i j}=\text { Trait } \\
& \mu=\text { Mean } \\
& T_{i}=\text { Effect of treatment, } i, 1-3(1=0 \% \text { date seeds, } \\
& 2=50 \% \text { date seeds, } 3=100 \% \text { date seeds }) \\
& e_{i j}=\text { Experimental error }
\end{aligned}
$$

Model 2 (for blood parameters and milk constitutes)

$\mathbf{Y}_{\mathbf{i j k}}=\boldsymbol{\mu}+\mathbf{T}_{\mathbf{i}}+\mathbf{S}_{\mathbf{j}}+\mathbf{T} \mathbf{S}_{\mathbf{i j}}+\mathbf{e}_{\mathbf{i j k}}$

Where:

$$
\begin{aligned}
& Y_{i j k}=\text { Trait } \\
& \mu=\text { Mean } \\
& T_{i}=\text { Effect of treatment, } i, 1-3(1=0 \% \text { date seeds, } \\
& 2=50 \% \text { date seeds, } 3=100 \% \text { date seeds }) \\
& S_{j}=\text { Effect of stage, } j, 1-3(1=\text { early, } 2=\text { mid, } 3= \\
& \text { late }) \\
& T_{\mathrm{ij}}=\text { The interaction between treatment and stage } \\
& \mathrm{e}_{\mathrm{ijk}}=\text { Experimental error }
\end{aligned}
$$


Second the economic evaluation: Alinear programming model to suggest optimum diet for fattening lambs in the study area.

Subject to

$$
\text { Min. } \mathrm{G}_{\mathrm{l}}=\sum_{\mathrm{j}} \mathrm{X}_{\mathrm{j}} \mathrm{P}_{\mathrm{j}}
$$

$\sum_{\mathrm{j}} \mathrm{a}_{\mathrm{ij}} \mathrm{X}_{\mathrm{j}} \geq \mathrm{C}_{\mathrm{j}} \quad$ (m inequalities in $\mathrm{n}$ variables)

And $X_{j} \geq 0$

m: Number of nutrients

$\mathrm{n}$ : Number of feed varieties

aij: number of kilograms of nutrient $i$ in one unit of food $j$.

$\mathrm{Cj}$ : The minimum number of kilograms of food element $\mathrm{i}$

required in one day.

Pj: The cost of one unit of food $\mathrm{j}$.

Table.1: Body weight changes $(\mathrm{kg})$ of the different experimental groups during gestation period

\begin{tabular}{lccc}
\hline Item & G1 & G2 & G3 \\
\hline Initial body weight & 37.90 & 37.70 & 37.90 \\
Weight just before lambing & 55.50 & 55.70 & 56.60 \\
Weight just after lambing & 43.20 & 44.40 & 45.50 \\
Weight gain during pregnancy period & 5.3 & 6.7 & 7.6 \\
Conceptus weight & 12.30 & 11.30 & 11.10 \\
\hline
\end{tabular}

G1; the control concentrate ration (0.0\% date seeds), G2; 50\% date seeds, G3; $100 \%$ date seeds as a partial or full replacer of corn in the concentrate ration.

On the other hand, productive parameters in terms of birth weight, weaning weight and marketing weight did not differ significantly (Table 2) and indicate better performance of the two date seed groups compared to control one. The decrease in post-weaning average daily gain might be attributed to decreased digestibility coefficients as a result of the relative increase in crude fibers as well as low protein content as reported by Khamiset al. (1989).

Table.2: Some productive traits (mean $\pm S E$ ) of the different experimental groups

\begin{tabular}{lccc}
\hline Item & G1 & G2 & G3 \\
\hline Average birth weight $\mathbf{( k g )}$ & $3.89 \pm 0.11$ & $3.93 \pm 0.09$ & $3.70 \pm 0.09$ \\
Average weaning weight $(\mathbf{k g})$ & $20.9 \pm 0.93^{\mathrm{B}}$ & $22.4 \pm 0.78^{\mathrm{A}}$ & $23.7 \pm 0.83^{\mathrm{A}}$ \\
$\begin{array}{l}\text { Average daily gain from birth to } \\
\text { weaning (g/h/d) }\end{array}$ & $188 \pm 10.36^{\mathrm{C}}$ & $207 \pm 10.26^{\mathrm{B}}$ & $221 \pm 10.36^{\mathrm{A}}$ \\
$\begin{array}{l}\text { Average marketing weight (kg) } \\
\text { Daily gain from weaning to marketing }\end{array}$ & $45.4 \pm 2.62$ & $44.7 \pm 2.49$ & $46.6 \pm 2.62$ \\
(g/h/d) & $136 \pm 20.54$ & $124 \pm 20.45$ & $127 \pm 20.45$ \\
Total milk yield (ml/h/d) & $441 \pm 21.2^{\mathrm{C}}$ & $495 \pm 21.2^{\mathrm{B}}$ & $585 \pm 21.2^{\mathrm{A}}$ \\
\hline
\end{tabular}

$\mathrm{G} 1$; the control concentrate ration ( $0 \%$ date seeds), G2; $50 \%$ date seeds, G3; $100 \%$ date seeds as a partial or full replacer of corn in the concentrate ration.

Weaning age $=3$ months, Marketing age $=9$ months

Different superscripts $(\mathrm{A}, \mathrm{B}, \mathrm{C})$ in a row indicate significance $(\mathrm{P}<0.05)$.

Growth rate, particularly in growing animals, is an important measure for the evaluation of new feed resources because it represents the total effect of most feed properties.
Date seed groups showed a better maternal and mothering abilities reflected on the pre weaning average daily gain where they scored 207 and 221 g/day for G2 and G3, 
respectively as compared to control one that scored the lowest value (188 g/day). These values were coincided with higher milk yield reported for the same respective groups (495 and $585 \mathrm{ml} / \mathrm{head} /$ day) compared with control one (441 $\mathrm{ml} / \mathrm{head} /$ day). Thus, weaning weight at 90 days old was found to be heavier in both G2 $(22.4 \mathrm{~kg})$ and G3 $(23.7 \mathrm{~kg})$ as compared to G1 (20.9 kg). However, weaning weights recorded for the three ewe groups were in accordance with that $(22.3 \mathrm{~kg})$ recorded by Abdel-Aziz (2004) and above that (18.5 kg) reported by Maharemet al.(2003).

Table.3: Analysis of variance of litter weight at birth, weaning and marketing of different experimental groups

\begin{tabular}{lrrrr}
\hline Source & \multicolumn{4}{c}{ Mean Squares } \\
\hline S.O.V & DF & Birth Weight & Weaning weight & Marketing weight \\
\hline TR & 2 & 0.03509174 & 24.12626774 & 67.74801421 \\
S & 1 & 0.45958563 & 26.48193775 & 192.93750000 \\
TR x S & 2 & 0.12247546 & 7.67202758 & 4.01753122 \\
Error & 30 & 0.24963459 & 20.75400959 & 29.80148810 \\
\hline
\end{tabular}

TR; treatment, $\mathrm{S}$; sex

\section{Economic evaluation}

The simple economic evaluation of the three diets are summarized in Table (4). Date supplementation in diets reduced the feeding costs during the whole fattening period by about 22.7 and $30.6 \%$ at level of 50 and $100 \%$ date seeds group, respectively. The diet supplemented with $100 \%$ was higher in econo mic efficiency by about $40 \%$ relative to control diet.

Table.4: Simple economic evaluation of incorporation of date seeds in the concentrate rations

\begin{tabular}{lccc}
\hline Item & G1 & G2 & G3 \\
\hline Weight gain (from weaning to marketing) & 24.5 & 22.3 & 22.9 \\
DMI (kg/head/180days) & & & \\
Roughage & 92.0 & 86.0 & 83.5 \\
Concentrate mixture & 121.5 & 106.2 & 114.0 \\
TDMI & 213.5 & 192.2 & 197.5 \\
Feed conversion efficiency (Kg DM/kg gain) & 8.7 & 8.6 & 8.6 \\
Roughage cost (LE/ton) & 800 & 800 & 800 \\
Conc. mixture cost (LE/ton) & 1200 & 950 & 750 \\
Total Feeding Costs (LE) & 219.4 & $169.7(22.7 \%)$ & $152.3(30.6 \%)$ \\
Fixed costs / head (LE) & 55 & 55 & 55 \\
Total costs (LE) & 274.4 & 224.7 & 207.3 \\
Selling income (LE)* & 465.5 & 423.7 & 435.1 \\
Net income (LE) & 191.1 & 199 & 227.8 \\
Economic efficiency & 69.6 & 88.6 & 109.9 \\
Relative economic efficiency & 100 & 127.3 & 157.9 \\
\hline
\end{tabular}

$* ; 1 \mathrm{~kg}=19.0 \overline{\mathrm{LE}}$

Relative economic efficiency

G1; control concentrate ration ( $0 \%$ date seeds), G2; 50\% date seeds, G3; $100 \%$ date seeds. TDMI; total dry matter intake.

There was a general trend from the literature cited that inclusion of date seeds in the concentrate with different levels, in sheep, goats and cattle rations, tended to reduce feed costs with values ranged from $67 \%$. The tendency of decreasing feed costs with date seeds in the concentrate mixture proved the success of such by product in ruminant rations without adverse effects on their reproduction and/or fattening performance.

Effect of feeding date seeds on milk production and composition:

Incorporation of date seeds in the concentrate diets of small ruminant tended to increase significantly $(\mathrm{P}<0.05)$ milk production. Ewes fed on either complete (100\%) or partially $(50 \%)$ date seeds supplementation in the concentrate ration scored higher milk yield (585.2 and $495.1 \mathrm{ml} / \mathrm{head} /$ day), over 3 months lactation period, as 
compared to the control one (441.1 $\mathrm{ml} / \mathrm{head} /$ day) (Table 5). Milk production increased by $32.7 \%$ in $\mathrm{G} 3$ (100\% date seeds) followed by $12.2 \%$ in G2 (50\% date seeds). The superiority of both date seed groups might explained the higher pre-weaning growth rate and the better mothering ability of their dams, and confirmed the above mentioned results concerning milk production.

Similar results were reported by E-Shaeret al. (1986) and Khamiset al. (1989). They demonstrated that lactating ewes fed date seeds as a whole diet (100\%) after grazing produced high milk yield than those fed olive pulp, but the percentage of milk fat and protein were higher with ewes fed olive pulp diet. In consistency with Abo El-Nor and kholif (1999) on Baladi goats, they found that milk yield was significantly higher in $100 \%$ date stone compared to either $50 \%$ date stone in the concentrate feed mixture or control group (100\% corn) with values being 793, 737 and $713 \mathrm{~g} / \mathrm{head} /$ day for the three groups, respectively. Likewise, Khattabet al., (2000) found that milk yield was insignificantly increased with ration contain $13 \%$ date stone.

Furthermore, up to $25 \%$ date seeds in the ration of lactating cows did not affect the daily milk yield (Mohamed 1987). Sabbahet al. (1997) observed no marked effect on daily actual or $4 \%$ fat corrected milk yield and composition when substituting yellow corn in the concentrate mixture by 50 and $100 \%$ date seeds. Salamaet al. (1993) on grazing pregnant and lactating sheep and goats in Sinai, found that milk yield increased insignificantly in both sheep and goats fed rations contained $40 \%$ date stone, $40 \%$ olive pulp and $20 \%$ concentrate mixture as compared with control group $(65 \%$ berseem hay and $35 \%$ concentrate mixture).

On the other hand, milk production tended to increase during early and mid stages of lactation (8 weeks) then declined steadily up to the end of lactation period (12th week) for all ewe groups. Such changes in milk yield within lactation period seemed to be logic since the peak milk yield was recorded during the 6th week (mid lactation stage) then declined (El-Sherif and Assad 2001) reflecting the hyper metabolic activity during pregnancy and lactation to save the higher demand of proper nutrition rich in energy, date seeds seemed to be a suitable alternative due to higher carbohydrate content and may play an important role in improving body condition score of the dams and growth performance of their lambs which are in accordance with other reports in the literature.

Concerning plant steroid effects, milk yield of Comisana ewes, fed on subterranean clover $(0.2 \%$ phytoestrogens on DM basis) compared with control group which fed Italian ryegrass hay, had increased insignificantly (Orruet al., 2005). They also added that these results support the hypothes is that the phytoestrogens could play a role on lipid and carbohydrate metabolism and on blood glucose level which might explain the increased milk production in date seed groups.

Milk composition of the different experimental groups as well as the analysis of variance of factors affecting milk production are presented in Tables (6 and 7). Although milk yield was affected significantly by inclusion of date seeds in the concentrate ration, milk composition was not affected among the different experimental groups. This result agreed with the previous results reported by Khattab (1976) and Allamet al. (1997) that the average of milk fat and protein were slightly increased $(\mathrm{P}<0.05)$ as the levels of date seeds increased in rations. These increases may be due to the high content of crude fiber in the diets containing date seeds as reported by (Kholif and Abo ENor 1998).

Table.5: Effect of treatment on milk yield and composition of experimental groups

\begin{tabular}{lccc}
\hline Variables & G1 & G2 & G3 \\
\hline Milk yield & $441.14 \pm 21.17^{\mathrm{C}}$ & $495.07 \pm 21.17^{\mathrm{B}}$ & $585.16 \pm 21.64^{\mathrm{A}}$ \\
Milk composition $(\%)$ & & & \\
Fat $(\mathbf{F})$ & $2.48 \pm 0.14^{\mathrm{A}}$ & $2.63 \pm 0.15^{\mathrm{A}}$ & $2.58 \pm 0.15^{\mathrm{A}}$ \\
Protein (P) & $4.11 \pm 0.06^{\mathrm{A}}$ & $4.19 \pm 0.06^{\mathrm{A}}$ & $4.27 \pm 0.06^{\mathrm{A}}$ \\
Lactose (La) & $4.59 \pm 0.05^{\mathrm{A}}$ & $4.53 \pm 0.05^{\mathrm{A}}$ & $4.64 \pm 0.05^{\mathrm{A}}$ \\
Total solids (TS) & $13.52 \pm 0.18^{\mathrm{A}}$ & $13.43 \pm 0.18^{\mathrm{A}}$ & $13.60 \pm 0.18^{\mathrm{A}}$ \\
Solids not fat (SNF) & $11.03 \pm 0.10^{\mathrm{A}}$ & $10.80 \pm 0.10^{\mathrm{A}}$ & $11.01 \pm 0.11^{\mathrm{A}}$ \\
\hline
\end{tabular}

G1; the control concentrate ration ( $0 \%$ date seeds), G2; 50\% date seeds, G3; $100 \%$ date seeds as a partial replacer of corn in the concentrate ration.

F; Fat, P; Protein, La; Lactose, TS; Total solids, SNF; Solid not fat 
Table.6: Analysis of variance of factors affecting milk production yield in experimental groups

\begin{tabular}{lcc}
\hline Source Of Variance & DF & Mean Square \\
\hline Treatment (T) & 2 & $277409.4^{* *}$ \\
Lactation stages (LS) & 2 & $751310.6^{* *}$ \\
LS X T & 4 & 33058.1 \\
Error & 114 & 17292.7 \\
\hline
\end{tabular}

$* * ; \mathrm{P}<0.01$

Table.7: Analysis of variance of milk composition

\begin{tabular}{llccccc}
\hline \multirow{2}{*}{ S.O.V } & \multirow{2}{*}{ DF } & \multicolumn{5}{c}{ Mean squares } \\
\cline { 2 - 6 } & & Fat & Protein & Lactose & Total solids & Solids not fat \\
\cline { 2 - 6 } Lactation stage & 2 & $5.17^{* *}$ & $36.85^{* *}$ & $19.29^{* *}$ & 3.71 & 0.66 \\
Treatments & 2 & 0.23 & 0.25 & 0.10 & 0.25 & 0.62 \\
LS x T & 4 & 2.07 & 0.17 & $0.43^{*}$ & 1.82 & 0.88 \\
Error & 112 & 0.85 & 0.14 & 0.10 & 1.32 & 0.45 \\
\end{tabular}

$* * ; \mathrm{P}<0.01$

The most traditional and non-conventional feedstock's in the study area:

Table 5 shows the most important traditional and non-traditional feedstuffs (peeled husk, non-peeled cotton gain, sesame, nougat-bale, olive oil, soybeans) available in the study area, their food content, the prevailing price at the time of the research, (Weight at the beginning offattening $30 \mathrm{~kg}$, daily increase $120 \mathrm{~g} / \mathrm{head}$ ).

\begin{tabular}{|c|l|l|l|l|l|}
\hline Variables & Feed type & $\begin{array}{l}\text { dry matter * } \\
\mathrm{kg} \mathrm{DM}\end{array}$ & $\begin{array}{l}\text { protein * } \\
\text { digested kg DP }\end{array}$ & $\begin{array}{l}\text { total digested } \\
\text { food * kg TDN }\end{array}$ & $\begin{array}{l}\text { Current price of } \\
\text { feed ton / pound } \\
* * *\end{array}$ \\
\hline $\mathrm{X}_{1}$ & Barley straw & 1,069845 & - & 0,6 & 900 \\
\hline $\mathrm{X}_{2}$ & Wheat straw & 1,07088 & 0,0069 & 0,5612 & 900 \\
\hline $\mathrm{X}_{3}$ & Driss Bressem & 1,04857 & 0,09315 & 0,6486 & 1450 \\
\hline $\mathrm{X}_{4}$ & Yellow corn & 1,03914 & 0,07475 & 1,0511 & 2350 \\
\hline $\mathrm{X}_{5}$ & Barley & 1,038105 & 0,07935 & 0,9683 & 2400 \\
\hline $\mathrm{X}_{6}$ & $\begin{array}{l}\text { non-peeled } \\
\text { cotton cake }\end{array}$ & 1,04627 & 0,2185 & 0,7682 & 2350 \\
\hline $\mathrm{X}_{7}$ & Sesame cake & 1,04857 & 0,48645 & 0,9683 & 1500 \\
\hline $\mathrm{X}_{8}$ & Peel bean & 1,035 & 0,069 & 0,644 & 2500 \\
\hline $\mathrm{X}_{9}$ & Date seeds & 1,081 & 0,08395 & 0,897 & 1200 \\
\hline $\mathrm{X}_{10}$ & Olive cake & 1,012 & 0,10925 & 0,391 & 200 \\
\hline $\mathrm{X}_{11}$ & Soybean cake & 1,0005 & 0,506 & 0,8625 & 300 \\
\hline Lowest daily needs per kg ** & 1,15 & 0,062 & 0,72 & \\
\hline
\end{tabular}

** Leonard C. Kearl, 1982, " Nutrient Requirements Of Ruminants In Developing Countries", International Feedstuffs Institute, UTAH Agricultural Experiments Station, UTAH Univ., Logan UTAH.

\section{CONCLUSION}

Productive parameters in terms of birth weight, weaning weight and marketing weight did not differ significantly and indicated better performance of the two date seed groups compared to the control group.The decrease in average daily gain post-weaning might be attributed to decreased digestibility coefficients as a result of the relative increase in crude fibers as well as low protein content in the date seeds comparing with the control diet. Lambs birth weight of the different ewe groups was found to be 3.89, 3.93 and $3.70 \mathrm{~kg}$ for G1, G2 and G3, respectively with differences being insignificant, while weaning weight was significantly $(\mathrm{P}<0.05)$ different with favour to date seed groups compared to the control group. Date seed groups showed a 
better maternal and mothering abilities reflected on the preweaning average daily gain, where they scored 207 and 221 g/day for G2 and G3, respectively as compared to the control group that scored the lowest value ( $188 \mathrm{~g} /$ day). Feed intake of concentrated rations relatively decreased in response to increase date seeds in the ration of lambs and this may be attributed to the highest content of crude fiber in G2 and G3 rations. Date seeds supplementation in the diets tended to reduce feeding costs by about 22.7 and 30.6 $\%$ at level of 50 and $100 \%$ date seed groups, respectively comparing with the control diet. The diet supplemented with $100 \%$ date seeds was higher in economic efficiency by about $57.9 \%$ relative to control diet. Over 3 months lactation period, ewes fed on either complete $(100 \%)$ or partially $(50 \%)$ date seeds in the concentrate ration scored higher milk yield $(585.2$ and $495.1 \mathrm{ml} / \mathrm{head} /$ day, respectively) as compared to the control group (441.1 $\mathrm{ml} / \mathrm{head} / \mathrm{day}$ ). In other words, milk production increased by either $32.7 \%$ in $100 \%$ date seeds group or $12.2 \%$ in $50 \%$ date seeds group as compared to the control group.

It could be concluded that date seeds as a cheap source of energy, might be used successfully and economically in small ruminant rations during different physiological stages without adverse effects, due to estrogen-like compounds, on their productive and reproductive performance.

\section{REFERENCES}

[1] Hamdy, A., S., ( 1998 ) Productive and Physiological Response Barki Sheep to Change in Certain Environmental Condition, Ph.D. Thesis, Faculty of Agriculture, Alazhar Univ., Egypt.

[2] Carles, A. B., (1983). Sheep Production In The Tropics. Oxford Univ. Press, New York .

[3] Dalton, C., (1980 ). An Introduction to Practical Animal breeding", Granada, London.

[4] Duncan, D. B. (1955). Multiple ranges and multiple F test. Biometrics, 11:1-42.

[5] El-Shaer, H. M.; Kandil, H. M. and Farid, M. F. A. (1986). The use of agro-industrial by-products in supplementary feeding of pregnant and lactating sheep and goats. Proc. of the 2nd Egypt. Brit. Conf. on Anim. and Poult.Prod. August 26-28, Bangor, UK.

[6] Nayera.Z. B., ( 1987 ), A study on Optimum Ewe Size Under Desert Condition, pH. D. Thesis, Faculty of Agriculture, Ain Shams Univ., Egypt.

[7] Leonard C. Kearl, 1982, " Nutrient Requirements Of Ruminants In Developing Countries", International Feedstuffs Institute, UTAH Agricultural Experiments Station, UTAH Univ., Logan UTAH. 